DOI: $10.34185 / 1991-7848.2018 .01 .01$

UDC 622.788.32:669.15*782-198.001.5

В.П. Піптюк, Д.М. Тогобицька, К.В. Баюл, І М. Логозинський, Б.А. Левін, О.П. Петров, С.В. Греков, Г.О. Андриєвський

\title{
ЕКСПЕРИМЕНТАЛЬНЕ ДОСЛІДЖЕННЯ ПІДВИЩЕННЯ ТЕХНОЛОГІЧНОСТІ БРИКЕТІВ ФЕРОСИЛІЦІЮ ДЛЯ ВИРОБНИЦТВА СТАЛІ
}

\begin{abstract}
Важливою фізичною характеристикою феросплаву є густина, бо саме вона визначає можливість його занурення в рідку сталь і забезпечує сприятливі умови плавлення. Промислові феросплави за величиною густини діляться на легкі (феросилікокальцій, висококремністий феросиліцій), важкі (феровольфрам, феромолібден) і з близькою за густиною до металевого розплаву (силікомарганець, силікохром). Актуальність вирішення проблеми підвищення технологічності феросиліцію ФС65 (густина його кускових фракцій порівняна з густиною шлаку) пов'язана із співвідношенням його густини $i$ густини шлако-металевого розплаву. 3 метою підвищення технологічності дрібнофракційного феросиліцію, який щорічно накопичується в процесі виробництва феросплава, випробували його брикетування $з$ добавкою «обважнювачів» (металева стружка) $і$ провели їх дослідне застосування. Представлені результати лабораторного випробування брикетування дрібнофракційного феросиліцію ФС65 з добавкою обважнювача для підвищення технологічності використання при виробництві сталі і оцінені характеристики, а також тривалість $і$ умови плавлення брикетів.
\end{abstract}

Ключові слова: дрібнофракційний феросиліцій, брикетування, властивості, використання.

Важливою фізичною характеристикою феросплаву $є$ густина, бо саме вона визначає можливість його занурення в рідку сталь і забезпечує сприятливі умови плавлення. Промислові феросплави за величиною густини діляться на легкі (феросилікокальцій, висококремністий феросиліцій), важкі (феровольфрам, феромолібден) і з близькою за густиною до металевого розплаву (силікомарганець, силікохром). Плавлення феросплавів, що вводяться в залізовуглецевий розплав у кусковому вигляді, залежно від густини протікає в різних умовах (рис. 1).

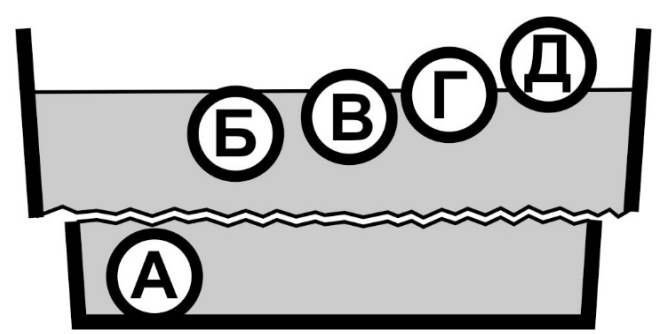

Рисунок 1 - Статичне положення куска феросплаву в

залізовуглецевому розплаві залежно від його густини:

$$
\text { А - } 7500 \mathrm{\kappa г} / \mathrm{M}^{3} \text {, Б - } 7000 \mathrm{\kappa r} / \mathrm{M}^{3}, \text { В - } 5000 \mathrm{\kappa г} / \mathrm{M}^{3}, \text { Г - } 3500 \mathrm{\kappa} / \mathrm{M}^{3} \text {, Д - } 2000 \mathrm{\kappa г} / \mathrm{M}^{3}[1]
$$

При введенні в рідку сталь кусок важкого феросплаву осідає на дно ковша і повільно розплавляється. Кусок легкого феросплаву при введенні в об'єм сталі спливає на поверхню і інтенсивно окислюється, що призводить до значної втрати провідного елементу. Кусок 3 густиною біля 5500-6900 кг/м ${ }^{3}$ повністю залучається до гідродинамічних потоків і циркулює в об'ємі ванни, внаслідок чого відбувається більш швидке і повне засвоєння провідного елементу феросплаву і його рівномірний розподіл в об'ємі сталі. Таким чином, значення раціональної густини феросплаву має конкретні межі, пов'язані з рухом його куска в сплаві. Існують різні погляди на раціональну густину феросплавів. Деякі автори припускають, що величина

(c) Піптюк В.П., Тогобицька Д.М., Баюл К.В., Логозинський І.М., Левін Б.А., Петров О.П., Греков С.В., Андриєвський Г.О., 2018 
раціональної густини з урахуванням густини розплаву сталі знаходиться в вказаному вище інтервалі [2].

Актуальність вирішення проблеми підвищення технологічності феросиліцію ФС65 (густина його кускових фракцій порівняна з густиною шлаку) пов'язана із співвідношенням його густини і густини шлако-металевого розплаву. 3 метою підвищення технологічності дрібнофракційного феросиліцію, який щорічно накопичується в процесі виробництва феросплава [3], випробували його брикетування 3 добавкою «обважнювачів» (металева стружка) і провели їх дослідне застосування.

При цьому брикети за своїми фізичними властивостями повинні відповідати наступним вимогам:

- Мати вагу, достатню для подолання шару шлаку під дією енергії вільного падіння, i густину (більше густини шлаку), що забезпечує найбільшу площу контакту з рідким металом при їх витанні на кордоні розділу фаз, тобто повинні якомога глибше занурюватися в метал.

- Мати достатній рівень опору стиранню та ударам, при транспортуванні та перевантаженні.

- Кількість вологи в брикетах має бути мінімальною.

- Зберігати свої фізичні характеристики (міцність, форму таке ін.) при зміні параметрів навколишнього середовища (температури, вологості таке ін.) при збереженні та транспортуванні.

- Мати достатній рівень термостійкості.

В ІЧМ НАНУ в якості основних матеріалів шихти брикетів використовували дрібнофракційні відсіви феросиліцію марки ФС65, які є вторинними сировинними ресурсами металургійного виробництва. Для обгрунтування компонентного складу брикету прийняте припущення, що основним фізичним параметром, який визначає придатність вторинної сировини до брикетування та подальшого використання при виробництві сталі є насипна густина шихти та брикетів на їі основі. Брикет повинен мати густину більшу, ніж густина ковшового шлаку. У попередніх дослідженнях густину шлаку приймали рівною 2700-3200 кг/м²,

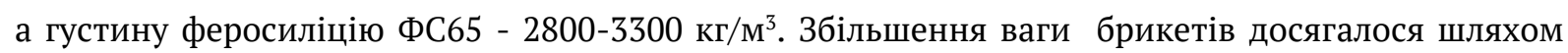
введення в склад шихти для брикетування ресурсоцінних дрібнофракційних залізовмістких матеріалів у вигляді чавунної (суміш високоміцного (ВЧ) i переробного (ПЧ) чавунів в співвідношенні 4 до 1) або сталевої стружки густиною 7800 кг/м³.

Виробництво експериментальних партій брикетованого феросиліцію здійснювали в лабораторії розробки технологій і обладнання для підготовки шихтових матеріалів ІЧМ НАНУ.

Чавунна i сталева стружка подрібнювалась до фракції -5 мм, а зі складу дрібнофракційного феросиліцію відсіювали найбільш придатну для виробництва брикетів фракцію -3 мм.

Підготовлені компоненти шихти ретельно перемішували в певних пропорціях (з 25\% чавунної стружки - 1-ий варіант; 3 40\% чавунної стружки - 2-ий варіант; 3 40\% сталевої стружки - варіант 3 і варіант 4 - $з$ чистим феросиліцієм). В якості в’яжучого компоненту використовувалась органічна добавка (до 5\% від маси). Пресування брикетів проводилось у сталевій циліндричній пресформі на лабораторній установці на базі гідравлічного пресу (рис. 2).

Ущільнення шихти для всіх варіантів ії складу відбувалося при однаковому значенні тиску пресування рівному 100 МПа. Спресовані брикети піддавали термічному зміцненню при температурі $100-130{ }^{\circ} \mathrm{C}$.

Для отриманих брикетів циліндричної форми (в середньому діаметр 30 мм і висота 20 мм) (рис. 3) визначено густину (табл.1) та проведено експериментальне дослідження температури плавлення. 


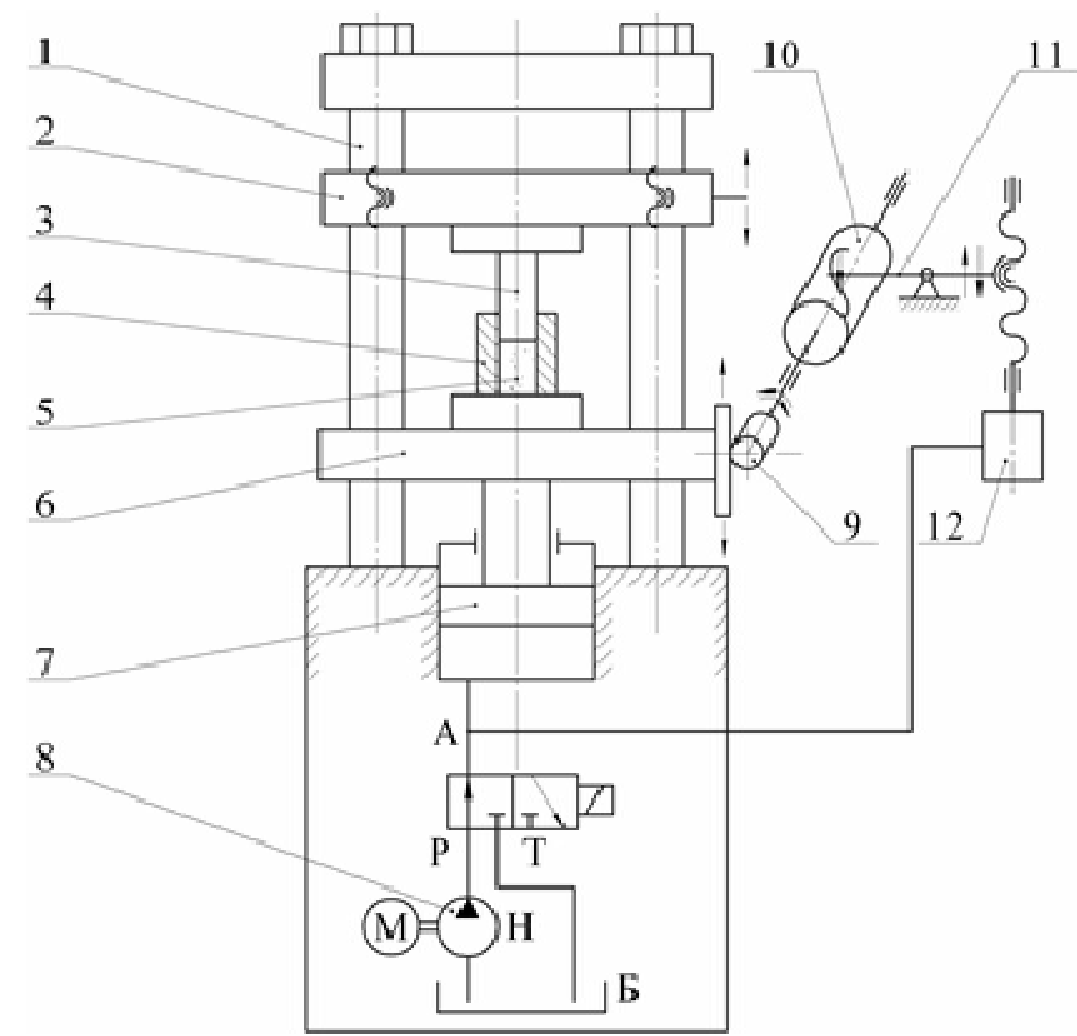

Рисунок 2 - Схема лабораторної установки для

оцінки придатності дрібнофракційних шихт до брикетування:

1 - колона; 2 - траверса рухома; 3 - пуансон; 4 - пресформа;

5 - матеріал що пресується; 6 - траверса гідроциліндру; 7 - гідроциліндр;

8 - насос; 9 - передавальний механізм; 10 - барабан самописця;

11 - перо самописця; 12 - перетворювач тиску
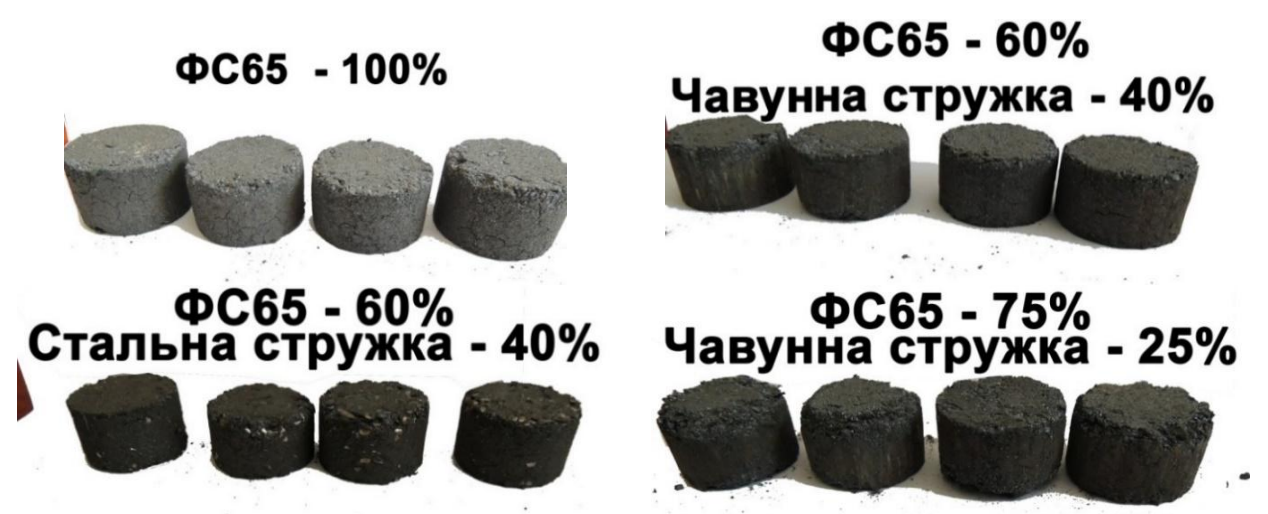

Рисунок 3 - Отримана партія брикетів (із зазначенням складу шихти)

Для визначення температури плавлення використовували лабораторне обладнання відділу металургії сталі (ВМС) ІЧМ НАНУ.

Лабораторний комплекс включав індукційну плавильну піч, високочастотний транзисторний генератор та пульт управління. Дослідний брикет розташовували в алундовому тиглі. Фіксацію температури плавлення проводили оптичним пірометром в момент утворення рідкої фази.

Результати досліджень властивостей брикетів залежно від складу наведені в табл. 1. 
Таблиця 1

Температура плавлення ( $\mathrm{T}_{\text {пл }}$ ), густина і вміст елементів в брикетах феросиліцію ФС65

\begin{tabular}{|c|c|c|c|c|c|c|c|c|c|c|c|c|c|c|c|c|c|}
\hline \multirow[b]{2}{*}{ 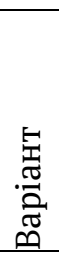 } & \multicolumn{4}{|c|}{ Матеріал брикету } & \multicolumn{10}{|c|}{ Вміст елементів*, ваг.\% } & \multirow[b]{2}{*}{ 焉 } & \multirow{2}{*}{$\begin{array}{l}\mathrm{T}_{\text {пл }} \\
{ }^{\circ} \mathrm{C}\end{array}$} & \multirow{2}{*}{ 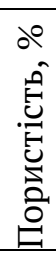 } \\
\hline & $F^{\prime}$ & 当 & 先 & $\begin{array}{l}n \\
0 \\
\theta \\
\theta\end{array}$ & $u$ & $\sum$ & के & $\infty$ & D & $\dot{U}$ & $\bar{z}$ & 3 & $\sum_{i}^{\infty}$ & 飞 & & & \\
\hline 1 & 20 & 5 & & 75 & $\stackrel{n}{0}$ & $\begin{array}{l}10 \\
12 \\
0\end{array}$ & $\begin{array}{l}\stackrel{\circ}{2} \\
\text { qे }\end{array}$ & $\begin{array}{l}a \\
\overrightarrow{0} \\
0\end{array}$ & $\begin{array}{l}8 \\
0 \\
0\end{array}$ & $\begin{array}{c}\text { Ñ } \\
0\end{array}$ & $\begin{array}{l}\sigma \\
0 \\
0\end{array}$ & 궁 & $\frac{+}{-1}$ & $\stackrel{\infty}{\infty}$ & 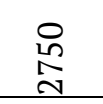 & 突 & $\begin{array}{l}\infty \\
0_{n}^{\prime}\end{array}$ \\
\hline 2 & 32 & 8 & & 60 & in & $\begin{array}{l}\text { Jे } \\
\text { ᄋ }\end{array}$ & $\begin{array}{l}\infty \\
\infty \\
\text { m. }\end{array}$ & $\begin{array}{l}\infty \\
\stackrel{0}{0} \\
0 \\
0\end{array}$ & $\begin{array}{l}n \\
0 \\
0\end{array}$ & $\begin{array}{l}\hat{N} \\
\hat{0}\end{array}$ & $\begin{array}{l}5 \\
0 \\
0\end{array}$ & $\begin{array}{l}\hat{N} \\
\text { ó }\end{array}$ & $\begin{array}{l}\vec{N} \\
\hat{0}\end{array}$ & in & 유 & 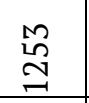 & $\begin{array}{c}0 \\
m \\
m\end{array}$ \\
\hline 3 & & & 40 & 60 & $\begin{array}{l}\stackrel{\infty}{N} \\
0 \\
0\end{array}$ & $\begin{array}{l}\text { 오 } \\
\text { on }\end{array}$ & $\vec{~}$ & $\begin{array}{l}0 \\
\text { O. } \\
0 \\
0\end{array}$ & $\begin{array}{l}0 \\
0 \\
0 \\
0\end{array}$ & $\begin{array}{l}M \\
0^{\prime}\end{array}$ & $\begin{array}{l}M \\
0 \\
0\end{array}$ & $\begin{array}{l}M \\
\stackrel{2}{0}\end{array}$ & $\begin{array}{l}\infty \\
\text { in } \\
0\end{array}$ & $\begin{array}{l}\text { 우 } \\
0^{0}\end{array}$ & $\begin{array}{l}\stackrel{2}{ } \\
\text { }\end{array}$ & 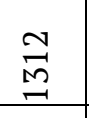 & مि \\
\hline 4 & & & & 100 & $\begin{array}{l}\approx \\
0 \\
0\end{array}$ & $\begin{array}{l}\text { P) } \\
0 \\
0\end{array}$ & $\begin{array}{l}8 \\
\text { 10 }\end{array}$ & $\begin{array}{l}0 \\
\text { Oิ } \\
0 \\
0\end{array}$ & $\begin{array}{l}\text { 융 } \\
0 \\
0\end{array}$ & 유 & б & $\begin{array}{l}\overrightarrow{0} \\
0 \\
0\end{array}$ & $\begin{array}{l}0 \\
0 \\
0\end{array}$ & $\begin{array}{l}\text { in } \\
\text { in }\end{array}$ & 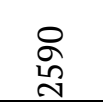 & $\underset{\text { త్ }}{\text { I }}$ & $\stackrel{\text { in }}{\mathrm{N}}$ \\
\hline
\end{tabular}

*) Хімічний вміст елементів ВЧ взято з ДСТУ3925-99, ПЧ з ДСТУЗ133-95, ФС65 з ДСТУ4127: 2002, сталі 45 з ГОСТ 1050

Густина брикетів зі сталевою стружкою дозволяє їх використовувати в металургійній практиці при доведенні металу за хімічним складом в ковші на установках доведення і на установках ківш-піч зі збільшеною масою (до 300 г) останнього, що сприяє проходженню брикету крізь шар шлаку або для його розкислення.

Слід зазначити, що при застосуванні чавунної стружки для обважнювання брикетів 3 ростом іï частки при брикетуванні збільшується не тільки густина але і вміст вуглецю, що скорочує сферу застосування (розкислення) виключно для високовуглецевих марок сталі. Застосування ж сталевої стружки для цих цілей може вирішити цю проблему, але пружинні властивості останньої є суттєвою перешкодою виробництва брикетів, тоді як чавунна стружка охрупчується і руйнується при пресуванні, що підвищує технологічність процесу брикетування.

Температура плавлення брикетів, виготовлених по варіанту 4, вище вказаної в статті [4], що, мабуть, пояснюється пористістю матеріалу. Температури плавлення брикетів потребують уточнення з часом накопичення експериментальних даних.

На базі експериментальної ділянки ВМС ІЧМ НАНУ досліджена тривалість плавлення отриманої партії брикетованого феросиліцію ФС65 на індукційній печі садкою 200 кг при виробництві сталі марки 110Г13Л. Фіксували температуру розплаву до введення брикетів. Індуктор на час експерименту відключали. Тривалість плавлення брикетів визначали візуально 3 допомогою секундоміра (рис.4). Отримані експериментальні результати зіставляли 3 чисельними даними. Гідродинамічні умови та тепловий стан в численних дослідженнях відповідали експериментальним. Експериментальні та розрахункові результати представлені в табл. 2.

Таблиця 2

Експериментальні та розрахункові дані плавлення брикетів

\begin{tabular}{|c|c|c|c|c|}
\hline \multirow{2}{*}{ 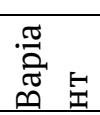 } & \multirow{2}{*}{ Температура металу, ${ }^{\circ} \mathrm{C}$} & \multicolumn{2}{|c|}{ Тривалість плавлення, с } & \multirow{2}{*}{ 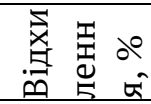 } \\
\hline & & Експериментальна & Розрахункова & \\
\hline 1 & 1550 & 150 & 157,2 & $+4,8$ \\
\hline 2 & 1550 & 140 & 154,3 & $+10,2$ \\
\hline 3 & 1550 & 240 & 251,6 & $+4,8$ \\
\hline 4 & 1550 & 360 & 295,6 & $-17,9$ \\
\hline
\end{tabular}


Зіставлення розрахункових і експериментальних даних (табл. 2) свідчить про прийнятні для металургійної практики відхилень результатів (до 18\%). Відхилення обумовлені, ймовірно, пористістю брикетів, а програмне забезпечення чисельних досліджень передбачає в якості вихідних даних властивості матеріалів добавки з нульовою пористістю. Програмний продукт 3 часом буде вдосконалений для застосування його до брикетованої сировини.

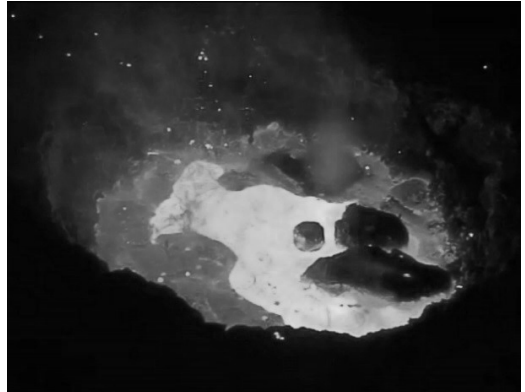

a

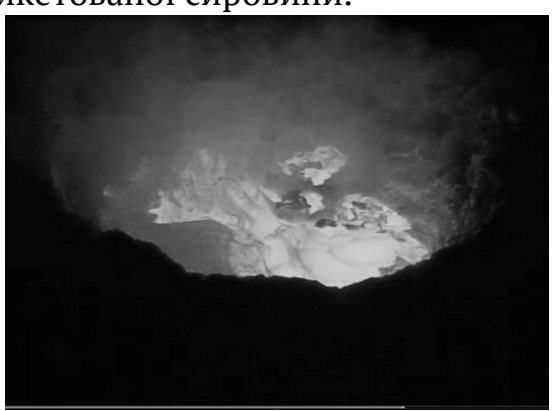

6

Рисунок 4 - Брикетований феросиліцій (варіант 2) в початковий період розплавлення (а) і перед розплавленням (б)

У зв'язку з кількісною обмеженістю вироблених партій брикетів вивчення їх фізичних і теплофізичних властивостей буде продовжено в майбутньому часі. Це обумовлено необхідністю розширення марочного і фракційного складу брикетованих феросплавів, забезпеченням спеціалізованим лабораторним обладнанням для здійснення експертної оцінки з використанням концепції спрямованого хімічного зв'язку.

\section{Висновки}

1.3 метою підвищення густини i, як наслідок, технологічності використання дрібнофракційних відсівів феросиліцію ФС65 при виробництві сталі, в лабораторних умовах ІЧМ НАНУ вироблені дослідні партії брикетів з добавкою обважнювачів (чавунна або сталева стружка) і проведено їх випробування.

2. Визначена температура плавлення і густина брикетів. Температура їх плавлення виявилася в інтервалі температур плавлення складових компонентів шихти, а густина, в більшості випадків, нижче густини шлаку, що зумовило можливість їх застосування для розкислення шлаку при позапічній обробці сталі або її розкислення в залежності від вмісту в ній вуглецю і густини брикетів.

3. Зіставленням результатів визначення тривалості плавлення брикетованого феросиліцію ФС65 3 різним шихтовим складом, отриманих експериментальним і чисельним методами, оцінена їх адекватність на рівні 5 - 18\%.

4. При розширенні сортаменту і по мірі накопичення експериментальних даних, запропонований метод дозволить здійснити експертну оцінку властивостей брикетів 3 використанням концепції спрямованого хімічного зв'язку.

ЛIТЕРАТУРА

1.Грищенко С.Г. Ферросплавная промышленность мира и Украины в 2014-2015 годах. / С.Г.Грищенко, В.С. Куцин, П.А. Кравченко, С.Л. Кудрявцев // Сучасні проблеми металургії. 2016. - Т.19. - В.1. - С.279-285.

2.Растворение ферросплавов в жидкой стали. Жучков В.И.,Носков А.С., Завьялов А.Л. Свердловск:УрО АН СССР, 1990. - 226c.

3.Выпуск ферросилиция из печи с разливкой в полости из отсевов дробления / П.А.Кравченко, С.М.Балашов, О.Н.Сезоненко и др.// Сучасні проблеми металургії. 2016. - T.19.-. B.1. - C.56- 64 .

4.Справочник по электротермическим процессам. Емлин Б.И., Гасик М.И. / -М.: Металлургия. -1978. - 288с.
1. Grischenko S.G. Ferrosplavnaya promyishlennost mira i Ukrainyi v 2014-2015 godah. / S.G. Grischenko, V.S. Kutsin, P.A. Kravchenko, S.L. Kudryavtsev // Suchasni problemy metalurhii. 2016. - T.19. - V.1. - S.279-285.

2. Rastvorenie ferrosplavov $\mathrm{v}$ zhidkoy stali. Zhuchkov V.I.,Noskov A.S., Zavyalov A.L. Sverdlovsk:UrO AN SSSR, 1990. - 226s.

3. Vyipusk ferrosilitsiya iz pechi s razlivkoy $\mathrm{v}$ polosti iz otsevov drobleniya / P.A.Kravchenko, S.M.Balashov, O.N.Sezonenko i dr. // Suchasni problemy metalurhii. 2016. T.19.- V.1. - S.56- 64 .

4. Spravochnik po elektrotermicheskim protsessam. Emlin B.I., Gasik M.I. / -M.: Metallurgiya. - 1978. - 288s. 


\section{EXPERIMENTAL STUDY OF INCREASED PRODUCTIVITY OF FERRO-SILICON BRIQUETTES FOR STEEL PRODUCTION}

Density is an important physical characteristic of ferroalloys, since it determines the possibility of its immersion in liquid steel and provides favorable conditions for melting. Industrial ferroalloys are divided by their density into light (ferrous silicocalcium, high silicon ferrosilicon), heavy (ferrofiber, ferromolybdenum) and close to the metal melt (silicomanganese, silicochromium). The urgency of solving the problem of increasing the processability of FS65 ferrosilicon (the density of its lump fractions is comparable to the density of slag) is related to the ratio of its density and the density of the slag-metal melt. In order to improve the manufacturability of small fractional ferrosilicon, which is accumulated annually in the process of producing ferroalloys, we tested its briquetting with the addition of "weighting agents" (metal chips) and carried out their experimental application. The results of the laboratory test of briquetting of fractional ferrosilicon FS65 with the addition of a weighing agent for improving the technological efficiency of use in the production of steel and evaluated characteristics, as well as the duration and conditions of melting briquettes are presented

Keyword: fine-fractional ferrosilicon, briquetting, properties, use.

\section{ЭКСПЕРИМЕНТАЛЬНОЕ ИССЛЕДОВАНИЕ ПОВЫШЕНИЯ}

\section{ТЕХНОЛОГИЧНОСТИ БРИКЕТОВ ФЕРРОСИЛИЦИЯ ДЛЯ ПРОИЗВОДСТВА СТАЛИ}

Важной физической характеристикой ферросплавов является плотность, поскольку именно она определяет возможность его погружения в жидкую сталь и обеспечивает благоприятные условия плавления. Промышленные ферросплавы по величине плотности делятся на легкие (феросиликокальций, висококремнистий ферросилиций), тяжелые (Ферровольфрам, ферромолибден) и с близкой по плотности к металлическому расплава (силикомарганец, силикохром). Актуальность решения проблемы повышения технологичности ферросилиция ФС65 (плотность его кусковых фракций сравнима с плотностью шлака) связана с соотношением его плотности и плотности шлако-металлического расплава. С целью повышения технологичности мелкофракционного ферросилиция, который ежегодно накапливается в процессе производства ферросплавов, испытали его брикетирования с добавкой «утяжелителей» (металлическая стружка) и провели их опытное применение. Представлены результаты лабораторного испытания брикетирования мелкофракционного ферросилиция ФС65 с добавкой утяжелителя для повышения технологичности использования при производстве стали и оценены характеристики, а также продолжительность и условия плавления брикетов

Ключевые слова: мелкофракционный ферросилиций, брикетирование, свойства, использование.

Піптюк Віталій Петрович - к.т.н., с.н.с., старший науковий співробітник, Інститут чорної металургії НАН України.

Piptiuk Vitaliy - Candidate of Technical Sciences, Senior Researcher, Institute of Ferrous Metallurgy of the National Academy of Sciences of Ukraine.

Тогобицька Дар'я Миколаївна - д.т.н., професор, завідуюча відділом фізико-хімічних проблем металургійних процесів, старший науковий співробітник, Інститут чорної металургії ім. 3.I. Некрасова НАН України.

Togobitska Daria - Doctor of Technical Sciences, Professor, Head of the Department of Physical and Chemical Problems of Metallurgical Processes, Senior Researcher, Institute of Ferrous Metallurgy named after. Z.I. Nekrasov National Academy of Sciences of Ukraine.

Баюл Костянтин Васильович - старший науковий співробітник, к.т.н., с.н.с, Інститут чорної металургії НАН України.

Bajul Konstantin - Senior Researcher, Candidate of Technical Sciences, Senior Researcher, Institute of
Логозинський Ігор Миколайович - заступник технічного директора ПрАТ "Електрометалургійний завод "Дніпроспецсталь" ім. А.М. Кузьміна"

Logozinsky Igor - Deputy Technical Director of the PJSC Electrometallurgical Plant Dniprospetsstal named after AM Kuzmin

Левін Борис Арнович - начальник технічного відділу, ПрАТ "Електрометалургійний завод "Дніпроспецсталь" ім. А.М. Кузьміна".

Levin Boris - Head of Technical Department, PJSC Electrometallurgical Plant Dniprospetsstal named after AM Kuzmin.

Петров Олександр Пилипович - науковий співробітник, Інститут чорної металургії НАНУ.

Petrov Aleksandr - Research Fellow, Institute of Ferrous Metallurgy of the National Academy of Sciences of Ukraine.

Греков Станислав Викторович - научный сотрудник, Институт черной чорной металлургии НАН Украины.

Grekov Stanislav - researcher, Institute of ferrous 
Ferrous Metallurgy of NAS of Ukraine. metallurgy of the National Academy of Sciences of Ukraine.

\section{Андриєвський Григорій Олександрович} молодший науковий співробітник, Інститут чорної металургії НАН України.

Andriyevsky Grigory - junior researcher, Institute of Ferrous Metallurgy of the National Academy of Sciences of Ukraine. 